\title{
Exotické umění a jeho potenciál vůči dnešní české společnosti
}

\author{
Kateřina Štěpánová \\ Katedra teorie kultury (kulturologie) Filozofické fakulty Univerzity Karlovy v Praze, Celetná 20, 11000 Praha 1
}

\section{EXOTIC ART AND ITS POTENTIAL TO PRESENT CZECH SOCIETY}

ABSTRACT The subject of this article is to analyze the relationship between man and artistic artifacts made out of home cultural tradition. The goal is to define the concept of exotic art, so that was non-judges categories, covering all the arts outside the parent, native cultural tradition. This art form is known by many misleading notions, it is necessary to bring this chaos of categories of foreign art to order. The definition of an exotic art in this work is based on an anthropological understanding of otherness and diversity of art and aesthetics in different parts of the world.

The emphasis is put on providing information to understand and define categories of exotic art, which can be used for convenience and classification. The main classification of the categories includes geography, politic, linguistic, social and religions.

Main attention was focused on introducing the essence and aesthetic perceptions of empirically-art artifact of foreign origin, which is to be seen without preconceptions as to the distinctive whole. Only through this approach can be a work of art from different cultural traditions to grasp in its wholeness, beauty of expression and can thus abstracting the essence of the artwork.

KEY WORDS exotic art; non-European art; art of natural nations; art of civilizations; global culture; art tradition

ABSTRAKT Předmětem tohoto př́spěvku je analýza vztahu člověka a uměleckého artefaktu, vytvořeného mimo mateřskou kulturní tradici. Cílem práce je vymezit pojem exotického umění tak, aby byl nehodnotící kategorií, zahrnující veškeré umění mimo rodnou kulturní tradici. Tento druh umění je označován mnohými zavádějícími pojmy, je proto nezbytné vnést do tohoto kategorizujícího chaosu cizího umění pořádek. Definice pojmu exotického umění v tomto příspěvku vychází z antropologického chápání jinakosti a odlišnosti umění a estetiky v různých částech světa.

Důraz je kladen na srozumitelné a informující vymezení kategorií exotického umění, jichž může být používáno pro snadnější orientaci a klasifikaci. Mezi hlavní klasifikační oblasti se řadí kategorie geografické, politické, lingvistické, společenské a náboženské.

Hlavní pozornost byla věnována mizející esenci a empiricko-estetickému vnímání uměleckého artefaktu cizího původu, na který je třeba nazírat bez předsudků, jako na svébytný celek. Jen díky tomuto př́stupu můžeme umělecké dílo z odlišné kulturní tradice uchopit v jeho celosti, kráse vyjádření a můžeme tak abstrahovat onu esenci, již do něj jeho autor ukryl.

KLÍČOVÁ SLOVA exotické umění; mimoevropské umění; umění př́rodních národů; umění civilizací; globální kultura; umělecké tradice

\section{EXOTICKÉ UMĚNÍ A JEHO POTENCIÁL VƯČI DNEŠNÍ ČESKÉ SPOLEČNOSTI}

„Umělecké dílo, dokonce i to, které nebylo uděláno př́mo pro nás, ale pro lidi jiných věků a jiných zemí, je tu především proto, abychom se z něho radovali. Tato zrejmá skutečnost upadá po hř́chu v zapomnèní."

(Hájek 1956, 7)
Myšlenka, obsažená v tomto citátu, motivovala ke vzniku jedinečného průvodce světem mimoevropského umění, souboru s názvem Umění čtyř světadílư, který byl dokončen v roce 1956, v redakci významného českého znalce a sběratele Lubora Hájka. Je důkazem, že již před více než padesáti lety začali někteří lidé upozorňovat na klíčovou změnu vztahu člověka k uměleckým předmětům v evropské kultuře. Snažili se najít a probudit v tomto vztahu mizející senzualitu, symboliku a tajemství, které je s každým novým desetiletím více vytlačováno 


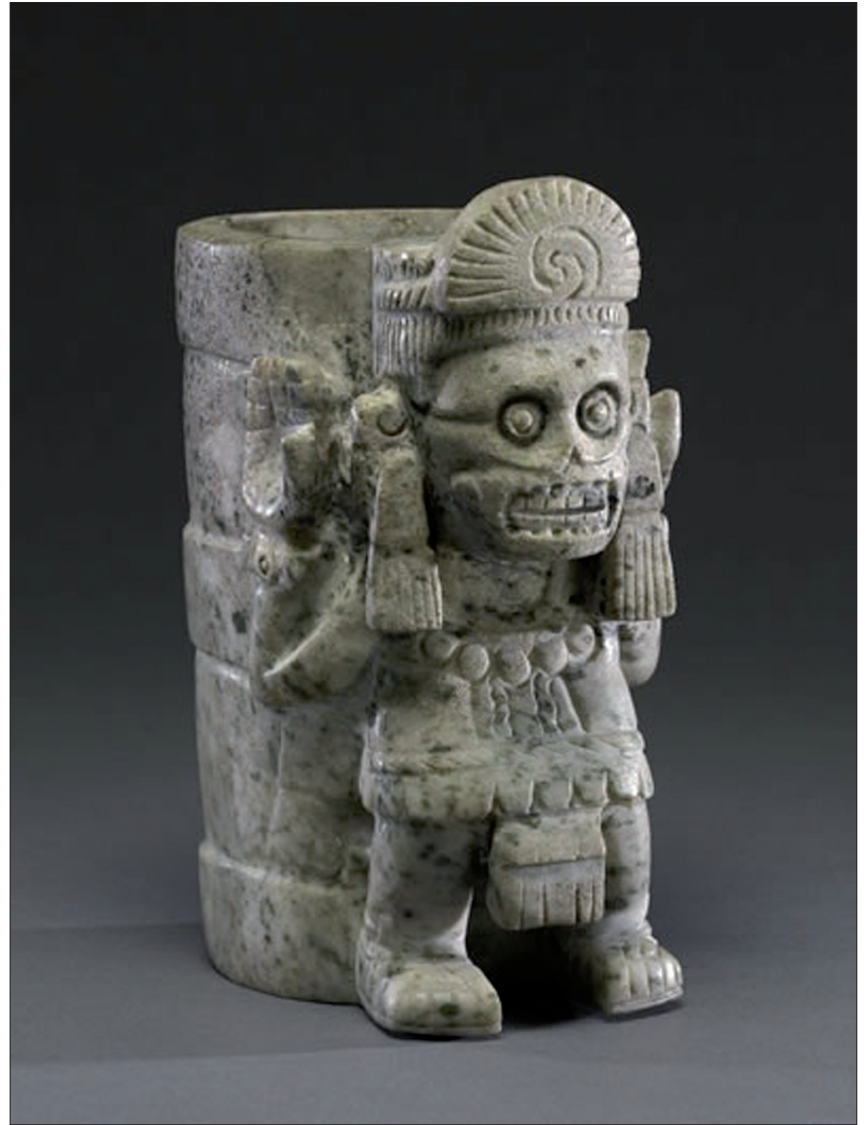

Obr. 1. Aztécké umění - obětní číše, materiál kámen (archiv autorky).

potřebami komerce, ekonomického tlaku a v neposlední řadě i masovým charakterem společnosti, v níž se nachází.

Nyní, po padesáti letech, ve společnosti „pozdní doby“ (zdroj Petrusek, 2006), můžeme jen smutně konstatovat, že vztah většiny lidí evropské kultury k umění se k lepšímu nezměnil. Naopak. Je tedy třeba znovu apelovat na důležitost senzuálního prožitku, vytvoření si pozitivního citového vztahu, který nám $\mathrm{z}$ uměleckého díla transformuje energii, tolik potřebnou ke zvládnutí narůstajícího napětí v mnoha životních oblastech současného Evropana. Pro vnímavého a otevřeného člověka je umění jedním z prostředků komunikace, proto je schopno, kromě přenosu informací, i transportu energie. Komunikuje zástupně za svého stvořitele a za svou kulturu, takže pokud jsme připraveni, můžeme, ze zdánlivě pouze materialistického objektu, získat mnohé další poznání (obr. 1).

Artefakty exotického umění nám ukazují dávnou historii naší společnosti. Jejich význam a odůvodnění jejich existence nacházíme ve společenských normách pospolitosti, společnosti venkova nebo, chceme-li, společnosti tradiční. Tak můžeme při pozorování exotického umění narazit na krizová témata dnešní globální civilizace, vztahující se zejména k pěti základním oblastem lidského života - vztah k sobě samému, vztah $\mathrm{k}$ přírodě, $\mathrm{k}$ př́ibuzným a rodině, vztah $\mathrm{k}$ vlastní společnosti a ke společnostem druhých (obr. 2).

Smutné je, že dnešní „ziskuchtivá společnost“ již téměř nedokáže vnímat tak jemné nuance, jako jsou právě inspirativní

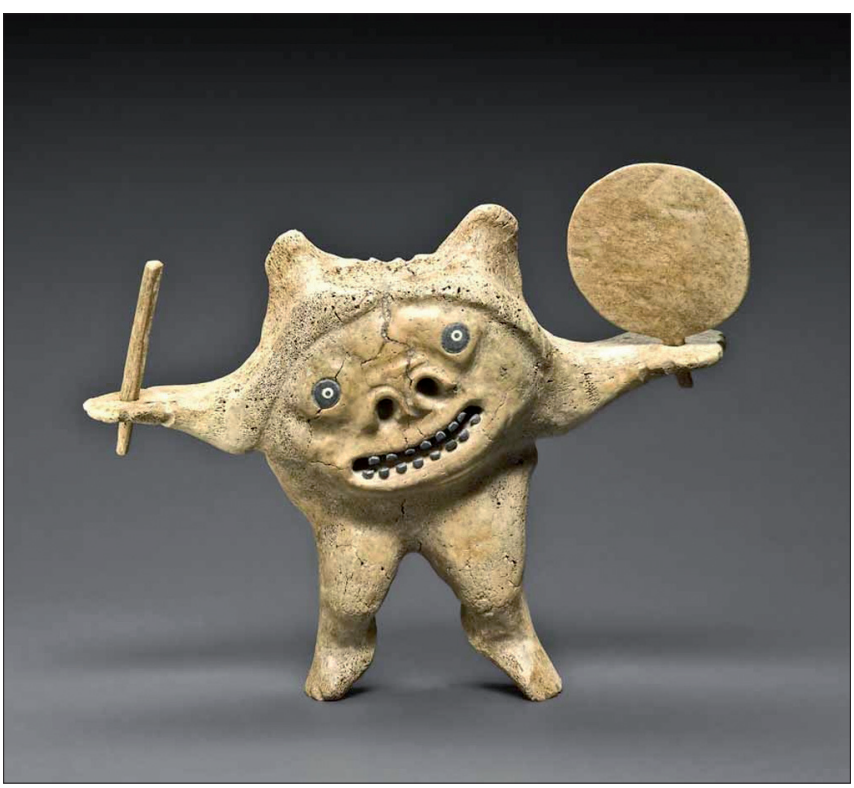

Obr. 2. Umění Inuitů - Tančící šaman, autor Nelson Takkiruq 1989, materiál velrybí kost, kámen, kolekce Winnipeg Art Gallery (zdroj http://wag.ca/art/ inuit/collection/66292, aktuálně 2.12.2010).

a vypovídající podněty při „komunikaci“ s některými uměleckými artefakty. A bohužel si tuto překážku neklademe jen před sebe, ale jako všechno, co považujeme za správné, jí vnucujeme ostatním částem světa, mnohdy aniž by ty o to stály.

\section{EXOTIKA, CIZOKRAJNOST A GLOBÁLNÍ KULTURA}

Označení „exotické uměni“ pro konkrétní skupinu uměleckých artefaktů má své opodstatnění a pevnou charakteristiku. Termín exotika je odvozen z řeckého slova exotikos, znamenající „cizí, vnějši“. Kořenem je řecké exó vyjadřující označení vně, mimo. České odborné publikace a slovníky se většinou shodují na výkladu slova exotika, jako na termínu zastupujícím označení pro zálibu v cizokrajných věcech, krajích a zvyklostech. Českému ekvivalentu tohoto slova se tak nejvíce blíží pojem cizokrajnost, ale i neobvyklost a zvláštnost.

Zajímavý je pohled také do amerických výkladových slovníků, které většinou popisují pojem exotický jako artefakt cizího původu, ne domorodý, známý z ciziny. Připouští však i existenci exotického ve vlastní kultuře, ale jen pod podmínkou, že ještě není plně naturalizováno a asimilováno - tyto př́klady se týkají zejména oblasti gastronomické, botanické a zoologické. Američané dále chápou exotiku i jako něco nápadně neobvyklého nebo divného, a to $\mathrm{v}$ dnešní společnosti zejména co se týče životního stylu nebo vzhledu. Zde už však cítíme, že se pojem přelil do komerčního slovníku.

Je dobře patrné, že pojem exotika bude obsahovat napříč světem různý výčet představ. Pro obyvatele brazilské oblasti Bahía patrně nebude největší exotikou vize rituálního tance na pláži, protože právě to je jejich kulturní tradicí, na kterou jsou od dětství zvyklí. Nabízí se proto objasnění pojmu. 
Autorka chápe termín exotika výhradně jako označení pro realitu $v$ oblastech s odlišnou kulturní tradicí, než je naše vlastní. Tomu, z obvyklých českých pojmů, nejlépe odpovídá již zmíněná cizokrajnost. Ovšem tento termín není vybaven dostatečnou konkretizací svého dosahu. Za cizokrajné není neobvyklé označit něco odlišného a nezvyklého, bez ohledu na původ. Při troše lingvistického absolutismu může Čech z konkrétního kraje považovat za cizokrajné cokoliv za hranicemi svého „revíru“.

Nemálo Čechů si pod pojmem exotika vybaví dovolenou $\mathrm{v}$ tropech (jak vyplývá $\mathrm{z}$ autorčina výzkumu uskutečněného $\mathrm{v}$ rámci diplomové práce $\mathrm{v}$ roce 2009). Právě $\mathrm{z}$ tohoto důvodu je nutné čistě vymezit autorčin záměr - označovat za exotiku rovnocenně cokoliv mimo naší kulturní tradici a oblast.

Pojem exotika nepatří k antropologickým pojmům, jak můžeme vysledovat $\mathrm{z}$ jeho absence $\mathrm{v}$ antropologických slovnících a publikacích. Také to není pojem, který by antropologové běžně používali, což je zajímavé, jelikož vlastně jedinečně vyjadřuje historicky primární oblast antropologického zájmu a do jisté míry i oblasti sekundární. Jako primární oblasti chápeme kolonie, první oficiální bránu do poznání cizokrajnosti. Když se později zájem přesunul i do minoritních kultur evropské společnosti, opět byly nejprve zkoumány skupiny odlišné, s neobvyklými prvky a zvláštními charakteristickými znaky, jako jsou přistěhovalci a uprchlíci. Cizokrajnost byla, a $\mathrm{z}$ velké části je, hlavním předmětem zájmu antropologie, je proto otázkou, proč se pojmu exotika antropologové vyhýbají. Možná za to může silný komerční podtón, který mu vtiskly cestovní kanceláře, aby nalákaly veřejnost na svou „nabídku“ exotiky. Představu lidí o tom, co je exotika tím pravděpodobně ovlivnily víc, než jsme si schopni připustit.

\section{POJEM UMĚNÍ V KULTUROLOGICKÉ ZKRATCE}

„(...) protože neexistují žádná pravidla, podle kterých určit, zda jsou obraz nebo socha správné, bývá obvykle nemožné přesně slovy vysvětlit, proč si myslíme, že jde o velké umělecké dílo. To však neznamená, že jsou všechna díla stejnè dobrá nebo že nelze diskutovat o otázkách vkusu. I když se třeba takovými diskusemi ničeho nedosáhne, primimèjí nás alespoň k tomu, abychom se na obrazy dívali, a čím více se na ně díváme, tím víc si uvědomujeme věci, které nám dřive unikaly" (Gombrich 1995, 35).

Definic umění je tolik co umělců a teoretiků, proto představme jen v krátkosti antropologický aspekt umění: autorka tento pojem chápe jako souborný název pro artefakt/y vytvořené jedincem nebo souborem jedinců, za účelem sebevyjádření individua, skupiny či ideje (zdroj Pijoan 1974-2001; Gombrich 1955; Soukup 2004). Umění je formou individuální a kulturní prezentace. Proces jeho vytváření nebo jeho finální podoba musí mít pro tvůrce nebo cílovou skupinu smysl. Hladina estetiky je v umění relativní. Umělecké dílo by mělo obsahovat esenci nebo jinak řečeno poselství, sdělení. Měla by z něj být cítit energie, kterou umělec či amatér do jeho stvoření za nějakým účelem vložil.

Vnímavější člověk tak pocítí jinou esenci ze suvenýru, kopie

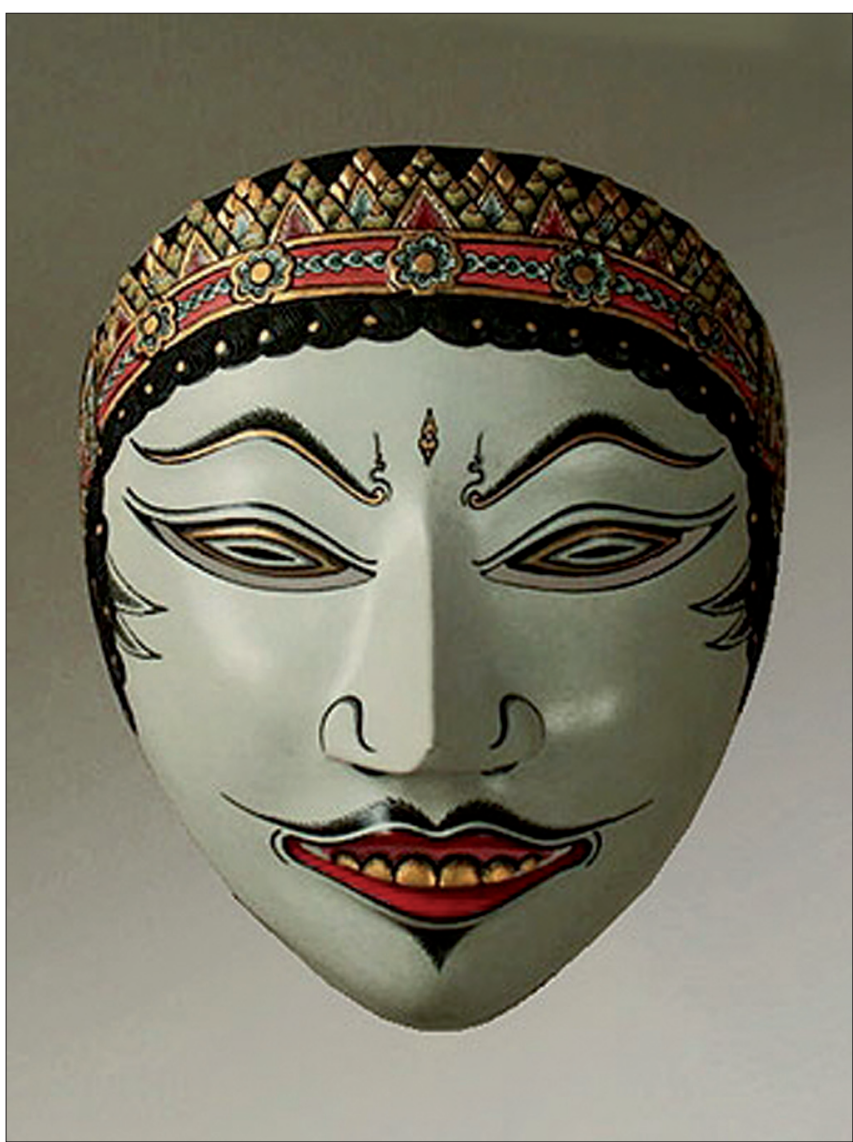

Obr. 3. Umění Jávy - maska krále tance Dalema, materiál malované dřevo (zdroj http://www.masksoftheworld.com/Bali/Bali\%20Java\%20mask\%2012. htm, aktuálně 2.12.2010).

než z předmětu vyrobeného jako originální kus mající svůj konkrétní, jedinečný účel a ve většině případů sakrální charakter, svého ducha (obr. 3).

\section{UMĚNÍ DRUHÝCH A JEHO DRUHY}

Z pohledu obyvatele České republiky můžeme konstatovat, že naše kulturní tradice spadá do evropského kulturního okruhu, dává mu základní parametry vzniku i vývoje (zdroj Bláhová 2007). Moderní evropská umělecká tradice je výrazně ovlivněna a utvářena i vnějšími vlivy, ale přesto má svůj jedinečný charakter a specifické znaky. Kulturně blízkou se nám také poslední dobou zdá tradice globalizovaných oblastí - Amerika, potažmo zamerikanizovaná Austrálie, jejichž velikým rozdílem, od kultury naší, je však právě čerpání možností z původního prostředí „nově“ dobytého kontinentu. V posledních staletích, pokud Evropa získávala inspiraci mimo své kontinentální hranice, bylo to $\mathrm{z}$ importu předmětů, z kulturních střetů s národy na hranicích nebo během objevných výprav. Oproti tomu, kultura americké a australské společnosti se po nějaké době po „usídleni“ začala inspirovat kořeny svého vlastního, nového kontinentu - ovlivnil jí styl původních obyvatel, náměty čerpaly z nového domácího prostředí a její 


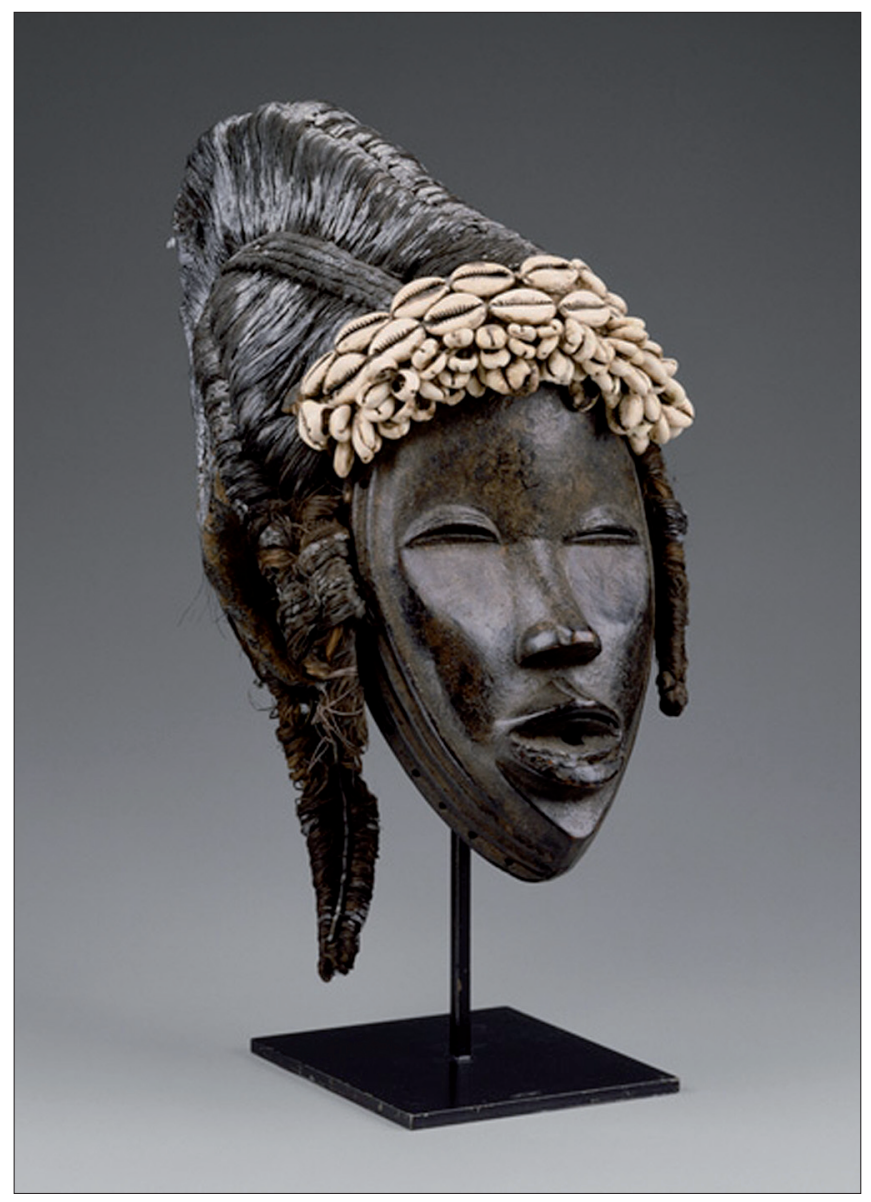

Obr. 4. Umění západní Afriky - maska, materiál dřevo, lýko, mušle; maska je umístěna v Boston Museum of Fine Art (archiv autorky).

umělci začali využívat specifických surovin, které se na jejich území nacházejí.

Svět umění tak dnes zahrnuje v nejpočetnější řadě globální umění - umění euro-americké tradice, vzniklé původně v Evropě, ovlivněné nejrůznějšími inspiracemi. Jedná se o umělecký styl a př́stup jedné civilizace, a to civilizace západní, se silnými kořeny křestansko-židovskými. Globální umění vzniklo evropskými kánony, rozšířilo se euro-americkými ekonomickými požadavky a módními názory a dnes je jeho vliv patrný ve většině světových oblastí. Ovšem v dnešní době se jaksi asimilovalo do podob, které už nejsou jasně vymezitelné, stejně jako pole jeho působnosti. Jeho hlavním charakterovým znakem je globální adaptabilita v podobě mnoha variací. Kromě tohoto uměleckého proudu existuje naštěstí ještě i řada tradic dalších.

Někteří historici a teoretici umění vymezují exotiku termínem mimoevropské umění, což je dnes však vystihující pouze $\mathrm{v}$ prrípadě, pokud zároveň vymezí svůj vztah i ke kultuře globální, která je v dnešní době z velké části, co se poměru obyvatel týče, mimoevropská.

Klasifikace jednotlivých kontinentů do geografických pásů podle zeměpisné šŕřky, pomáhá jasněji určit hranice konkrétního klimatu, vymezit je vůči rovníku. Tak se vyskytlo logické rozdělení většiny kontinentů na části severní, střední a jižní, jejichž společnosti žijí v obdobných klimatických podmínkách, zásadně ovlivňujících psychiku i fyzické dispozice jednotlivců v dané oblasti. Na klasifikaci umění podle typu prrírodních podmínek má ale největší zásluhu materiální zásoba př́rodnin, jimiž dané oblasti disponují, protože pro mnohá společenská uspořádání jsou stále přírodní suroviny základním materiálem jejich uměleckého vyjádření. Mủžeme si také všimnout, že i ve společnostech, které jsou schopny obstarat si jakékoliv suroviny pro své umělecké počiny, se stále najdou minority, zejména ty chudší, které navzdory pokroku využívají prrírodních materiálů ze svého životního prostředí (obr. 4). Zde můžeme spekulovat, zda se jedná o skupiny tzv. přírodních lidí - myšleno s hanlivým přízviskem (jako například hippies, cikánské skupiny a mnoho dalších) nebo zda to jsou ekologičtí vizionáři, kráčející proti proudu konzumní a sebe-devastující společnosti ...

Zpravidla se ještě zmíněné geografické oblasti dělí do mnoha dalších kategorií podle oblastí či území konkrétních kmenů. Jejich výčet je obrovský a nejednotný. Ovlivnění jejich uměleckého stylu podléhá tedy lokaci dané kultury - charakteristice životního prostředí (klima, fauna a flóra), ale také intenzitě kulturní výměny a konkrétním životním podmínkám.

V každé ze skupin se nacházejí př́buzné znaky, typické pro danou geografickou oblast a variující v rámci většiny jejich oblastí a kultur.

Umění můžeme kategorizovat také podle států, na jejichž území bylo vytvořeno. Jedná se o klasifikaci přehlednou, srozumitelnou a nespornou, na rozdíl od kategorizace sociálněkulturní, kde je situace, zejména na okrajích společností, více nebo méně „rozmazaná“. Tento způsob klasifikace umění je oblíbený zejména v amerických publikacích.

Samozřejmě nesmíme také opomíjet jeden $\mathrm{z}$ dalších pilírư reality, a tím je lingvistika. Rozdělení světa na oblasti jazykové př́islušnosti je zobrazeno již v zeměpisném atlase pro základní školy, proto o jeho důležitosti není pochyb. S větší vážností rozpracoval tuto myšlenku roku 1921 ve své světoznámé práci Language: An Introduction to the Study of Speech (Jazyk: Úvod do studia řeči) Edward Sapir, který jako jeden z prvních formuloval myšlenku jazykového relativismu.

Jednotlivé jazykové rodiny interpretují svět za pomocí originálního souboru slovní zásoby, gramatických pravidel, fonetiky a ostatních složek vyjadřování. Tyto jazykové rodiny tvoří jazykové bloky, vykazující jistou příbuznost svých prvků v rámci konkrétního území. Proto nám i lingvistické rozdělení světa nabízí jistou logickou možnost klasifikace uměleckých tradic. Jednotlivé kultury uchopují své bytí prostřednictvím věcí v jejich bezprostředním okolí, vysvětlují si skutečnosti a reagují na ně - to vše se děje konkrétní podobou lokálního jazykového systému a jeho prostřednictvím, vznikají i umělecké artefakty. Tak je nám někdy exotické umělecké dílo nesrozumitelné a jediným klíčem $\mathrm{k}$ jeho správnému pochopení je jazyk. Pokud budeme toto dílo odsuzovat jako nepochopitelné, je chyba pouze v nás - při dobré znalosti domorodého lingvistického systému a jeho tradic, se může jednat o běžnou, či alespoň pochopitelnou konstantu. Do takovéto situace se 
můžeme dostat zejména při studiu mýtů, písní nebo jakékoliv jiné mluvené či psané podoby uměleckého projevu. Původní poselství může být špatně interpretováno nebo „ztraceno v př̀ekladu“.

Lingvistickou kategorizaci umění využijeme zejména při klasifikaci umění př́rodních národů v oblastech jejich hojného výskytu, jako je např́iklad Amazonie, kde najdeme řadu příbuzných jazykových rodin se specifickými společenskými znaky (zdroj Lévi-Strauss 1955; 1966).

Pro potřeby sociálně-kulturní kategorizace exotického umění byly po zvážení tyto artefakty rozděleny do dvou základních skupin - umění civilizací a umění prírodních národủ. Tato klasifikace je inspirována myšlenkami Josefa Čapka z jeho knihy Umění prírodních národů (1938; 1996).

\section{UMĚNÍ CIVILIZACÍ}

Jako civilizace chápeme lidské společnosti disponující písmem, složitější sociální stratifikací, společenskou organizací, duchovní a technickou vyspělostí. Umění v rámci civilizace můžeme klasifikovat několika způsoby. Mezi povedené příklady se řadí schéma amerického kritika umění Clementa Greenberga (zdroj Greenberg 1972). Prakticky rozdělil kulturu jedné civilizace do tří oblastí: 1. kultura umělecká, která je novátorská, avantgardní a experimentuje; 2 . kultura akademická, která dokonale zvládá techniku, ale je konzervativní a nudná; 3. zvulgarizovaná akademická kultura neboli kýč. Toto schéma je k nalezení u největších moderních civilizací, nebo oblastí s nimi sousedících. Jedná se o nesporná stadia vývoje umělecké scény u kultur, které mají velké množství publika a ekonomických prostředků, spolu s komerčním a masovým přístupem jejich členů k uměleckým dílům.

Za umění civilizací je považováno, kromě civilizace Západní, zejména umění Orientální (japonské, čínské, indické, turecké, blízkovýchodní, arabské), egyptské, ruské, aztécké, incké a mayské.

\section{UMĚNÍ PŘíRODNÍCH NÁRODŮ}

Př́rodními národy máme na mysli, stejně jako Josef Čapek (1938; 1996), národy nedisponující písmem, mající jednoduchou společenskou stratifikaci, organizaci a jednoduché technologie. U umění př́rodních národů platí, že „(...) mnoho uměleckých artefaktů hraje určitou úlohu při obřadech, a pak nejde o to, je-li socha nebo obraz podle našich měrítek něco krásného, nýbrž zda ,plní svioj účel', to znamená, zda dokáže vyvolat žádané kouzlo. Umělci navíc pracují pro př́slušníky vlastního kmene, kteři přesně vědí, co každý tvar nebo každá barva znamená. Nepožaduje se po nich, aby nèco mènili, nýbrž aby svému dílu věnovali veškerou dovednost a um" (Gombrich 1995, 43).

„(...) nemůžeme rozumět umění minulosti, neznáme-li účel, jemuž mělo sloužit. To můžeme pochopit (...) když odjedeme $z$ civilizovaných zemí a navštívíme národy, jejichž zpưsob ži-

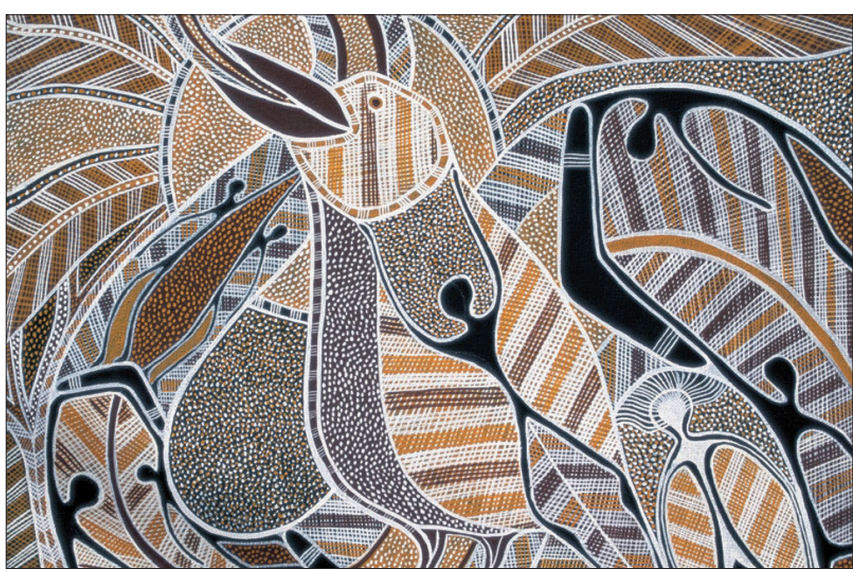

Obr. 5. Tradiční umění Austrálie - aboriginal art (archiv autorky).

vota se stále ještě podobá podmínkám, v nichž žili naši dávní předkové. Nazýváme tyto národy primitivními nikoli proto, že jsou jednodušši než my - jejich myšlení je často složitější než naše, nýbrž proto, že mají mnohem bliže ke stavu, $z$ něhož se veškeré lidstvo kdysi vyvinulo. Pokud jde o užitečnost, neexistuje pro tyto primitivy rozdíl mezi budováním něčeho praktického a uctíváním model. (...) obrazy a sochy mají působit jako kouzlo. Nemůžeme doufat, že tyto zvláštní začátky umění pochopíme, jestliže se nepokusíme vmyslet do duševních pochodì primitivních národů a poznat, jaké záżitky je vedly $k$ tomu, aby obrazy nepovažovaly za něco, na co se člověk rád dívá, nýbrž za cosi mocného, co používá. Myslím, že není těžké znovu takový pocit zakusit. Je k tomu třeba pouze vưle být sami $k$ sobě zcela uprímní a zkoumat, zdali něco z primitiva nezustalo i v nás. (...) Primitivové nikdy zcela presně nerozlišují mezi skutečností a obrazem" (Gombrich 1995, 41).

Pod nálepkou „mimoevropské umění“ si dlouho mnohé generace představovaly právě umění prrírodních národů. $V$ dnešní době je nanejvýš nutné tuto chybu napravit, protože přírodních národů rychle ubývá a i do velmi odlehlých končin se dostává v odstředěné podobě ekonomický požadavek globalizovaného světa, požadavek na místní obyvatele, komerční vetřelec jménem turismus. Tomuto stále silnějšímu vládci podléhají chudé exotické oblasti v podobě degradace jedné složky své kultury na komerční zábavu pro kulturu jinou, bohatší. To se projevuje např́klad ve velkovýrobě suvenýrů autonomních kulturních skupin, prodávaných jako originální nativní předměty. Tento jev můžeme také najít $\mathrm{v}$ hraných tradičních rituálech, kdy jejich účastníci za drobné spropitné odhalují sakrální zázemí svého společenství. Tento přistup k vlastnímu umění se tak nutně přibližuje onomu schématu umění civilizací podle C. Greenberga, ještě lépe jedné z jeho složek. A to té poslední, zvulgarizované akademické kultuře neboli kýči. Pokud jsou ještě nějaké pochyby, je nutno je vyvrátit - samozřejmě, je to důsledkem chování „naší civilizace. Jako umění přírodních národů chápe tato práce umění domorodé Afriky, obou Amerik (s výjimkami civilizačního umění Aztéků, Inků, Mayů a oblastí přistěhovalců z Evropy a jejich potomků), dále domorodé umění Grónska, Austrálie a Oceánie a izolovaných venkovských oblastí Asie (obr. 5). 
V sociálně-kulturních kategoriích uměleckých regionů jsou nespornou inspirací klasikové cyklických koncepcí schematizace světa, kterým fakt náboženské př́islušnosti také jistě při členění světových společností pomohl. Jsou jimi Oswald Spengler a jeho dílo Zánik Západu (1918; 2010) a Arnold J. Toynbee se Studiem dějin (1934; 1995). Spengler nechal svému světu dominovat osm kultur a Toynbee pět současných civilizací. Na tomto typu schématu lze pozorovat právě převážně náboženskou vyhraněnost, jež ovlivňuje celou další podobu konkrétních kultur, a tím je řadí do zmíněných okruhů. Je nutno souhlasit, že většina civilizací, nejen tak, jak byly vymezeny Spenglerem a Toynbeem, udržují psychologické pouto svých členů právě prostřednictvím náboženské svrchovanosti a povinnosti, která dává jejich činům jednotný směr. Náboženskou orientaci považuji za jeden z hlavních pilíruo společenské jednoty uvnitř velkých civilizací. A to i v době největší sekularizace, době dnešní globální kultury, protože ještě stále tvoři většinu našich kulturních dějin, tak jak je předáváme dalším generacím, doba ovlivněná konkrétním bohem.

Jednotlivé umělecké artefakty z konkrétních kultur můžeme vždy rozdělit do sekcí posvátné nebo profánní. Naopak pokud si skládáme obraz konkrétní kultury z jejích jednotlivých artefaktů, musíme brát obě tyto složky v potaz, $\mathrm{v}$ rovnoměrném zastoupení.

Původ všeho umění je v magii, jejímž vznešenějším názvem je náboženství (Čapek 1938; 1996). Proto jedním ze základních pilírư kategorizace umění jsou také oblasti náboženské prríslušnosti.

\section{UTILITÁRNÍ UMĚNÍ}

Př́stupy k uměleckým artefaktům se v průběhu dějin zásadně proměňovaly pod tíhou společenských událostí. Jaká je tedy podstata vztahu člověka ke svému výtvoru? Mezi počáteční vlastnosti tohoto vztahu patří zejména pragmatičnost. Člověk vytvářel něco, co mu pomáhalo v jeho žití, usnadňovalo jej, zvýhodňovalo a podřizovalo si okolní prostředí. Míra estetické kvality se časem zvyšuje, ale není prvotním záměrem. Na počátku bylo vymezení člověka vưči přírodě. Tyto pozůstatky jsou dnes ještě na několika místech naší planety patrné, a to převážně ve společnostech přírodních národů, ale i tam už se situace rychle mění.

Zásadní dichotomii najdeme v rozporu, co jednotlivé společnosti považují za umění. Velké civilizace $\mathrm{v}$ dobách svého vzniku, ale zejména př́rodní národy, vyrábějí artefakty za nějakým účelem. Výtvory mají tedy pro své členy praktické využití, zcela jasnou funkci a někdy, když je dlouhá chvíle, mohou být doplněny estetickými prvky. Faktem je, že až do nedávné doby existovaly společnosti, které význam slova umění vůbec nechápaly, ani jej neměly ve své slovní zásobě. Nosily šperky jako výraz společenského postavení, zdobily keramiku, aby na první pohled rozlišily obsah nádob, tkaly barevné látky, aby dobře viděly na své děti pobíhající ve velké vzdálenosti od obydlí. Co je potom to umění? K čemu slouží? Jaký má význam? Kdy už je něco za umění považováno a kdy ne?
Z tohoto hlediska se zdá nelogické vystavovat ve vitríně indiánské hřebeny, nádoby na sádlo a ponča. Je to, jako kdybychom se chodili dívat na použitý kartáček na zuby, plastovou přepravku a tepláky. My ovšem můžeme, nebo dokonce musíme, uznat etnologickou a vzdělávací hodnotu takovýchto muzeí, právě díky tomu, že vystavené předměty brání ochranná známka „umění“. Pokud tento status předměty neměly, nestaly by se součástí sbírek ani by nezůstaly po generace uchovávány.

Předměty ryze umělecké povahy u cizokrajných národů, zejména těch prrírodních, vznikají až od konce 19. století a to zejména na poptávku Evropy. Do té doby je přesnější označení užitkové predměty, předměty denní potřeby či sakrální artefakty. Zde si uvědomme, že za moderní cizokrajné umělecké dílo, podobně jako v naší vlastní společnosti, dnes považujeme předměty, které aktuálně nemají žádnou pragmatickou funkci, slouží jen k estetické duchovní potěše. To dokazuje množství obchodů se suvenýry, stejně jako zástupy chudých domorodců kolem turistických lokalit po celém světě, prodávající „tradični“ kmenové „umění. Kolik je těch, kteří si koupili čerstvě dokončenou africkou masku a pověsili si ji doma na zed', aniž by na ni měli další nároky, a kolik těch, co mají na polici v knihovně čínský slunečník, sádrovou sfingu nebo sochu Buddhy? Tento kýč, to je pravé cizokrajné umění. Protože to ostatní slouží k používání, je součástí aktivního chodu lidského života. Jsou to předměty posvátného a profánního využití.

Společnosti ve fázi civilizace demonstrují svou moc schopností přebytku, a to ve všech oblastech. V obrovském množství estetických předmětů se za umění považuje cokoliv, co je svým tvůrcem jako umění nazváno. Společnosti dnešní doby poskytují svým umělcům zatím největší množství podnětů, materiálního vybavení a uměleckých kontaktů po celém světě. Nacházíme nové hranice umění. V dobách, kdy si plátno, barvy a štětce může obstarat téměř každý, kdo je umělcem a kdo ne? Skoro by se zdálo, že opravdovým umělcem je ten, kdo prodá své dílo za víc, to znamená ten, který má dobrého manažera a jehož díla visí v galeriích. Ovšem při pohledu z druhé strany máme pocit, že právě ti, co si doma malují obrázky na zed'a zdobí hrnky na kakao, se více přibližují té prvotní postatě „umělce“ nebo spíš vlastně člověka, který si zpř́ijemňuje své domácí prostředí. Když je dlouhá chvíle, zkrášluje si život estetickými prvky na svých oblíbených užitkových věcech.

Nezměnila se jen podstata umění, společenských vztahů a možností realizace. Tou nejdůležitější a zároveň nejnaléhavější změnou prošel vztah člověka s přírodou. Dnes stále diskutovanější téma o podřezávání větví a ekologických katastrofách je patrné ve všech aspektech lidského chování, jednání a prožívání, a to zejména v oblastech postižených globalizací. Pokud si nesprávně uvědomujeme své místo ve světě, pokud před ničím nemáme respekt a úctu, a pokud nás nezajímají důsledky našich činů, přestaňme našemu umění říkat Umění a zaved’me prostý pojem dekorace. Stejně je právě toto hlavní funkcí světového proudu umění dnešní doby. Nebo je to obráceně? Je uměním kýč a dekorací amatérská potřeba vyjádřit se? 
Východiskem z neštastné situace je renesance lidské podstaty. Znovunalezení primárního pouta $\mathrm{k}$ přírodě, obnovení úcty a zavedení péče o to životadárné, co zapříčinilo naši existenci. K tomuto cíli vedou mnohé dveře, ekologickými ideály počínaje, návštěvami etnologických muzeí konče. Setkávání s cizokrajnými kulturami, prostřednictvím jimi vytvořených artefaktů, nám může pomoci při hledání správné životní cesty, zejména pokud si uvědomíme životní podmínky jejích obyvatel, jejich záměry a tvůrčí myšlenky.

Každá národní kultura má svou vlastní dominantu, nebo soubor dominant, tvořící kulturní prostor, uměleckou, náboženskou a tradiční stránku společnosti, tím se od sebe kultury odlišují. Historicky vzniklý soubor etnických kulturních norem a hodnot nejen charakterizuje kulturu etnické skupiny, ale stává se hlavním článkem národního uvědomění, dává mu osobitý rytmus, který je ve své celosti jedinečný. Současná světová situace vyžaduje pluralitní a tolerantní prrístupy, jimž mohou „kontakty“ s odlišnými kulturami a jejich výtvory napomoci. Podoba umění je odrazem př́stupu k životu, proto je nasnadě jak sebereflexe, tak empatie. V dnešní, globální podobě kultury se více než kdy jindy setkáváme s odlišností, ale málokdy ji správným způsobem interpretujeme. Je proto třeba se nejprve zamyslet, jaká jsou naše očekávání, která před nás staví vlastní kultura, ta potom odhodit a bez předsudků a přání předstoupit před exotické umělecké dílo a vnímat ho v jeho ojedinělé podobě a naléhavosti. Protože krása není to nejdůležitější. Protože krása je relativní.

\section{LITERATURA}

Auboyer, Jeaninne - Goepper, Roger (1972): Umění Dálného východu. Praha: Artia.

Bláhová, Kateřina (2007): Cizí, jiné exotické v české kultuře 19. století. Praha: Academia.

Čapek, Josef (1996): Umění př́rodních národů. Liberec - Praha: Dauphin.
Exotismy ve výtvarném umění XX. století v Čechách a na Moravě. Katalog výstavy. Praha: České muzeum výtvarných umění, 2008.

Gombrich, Ernst Hans (1995): Př́běh umění. Praha: Argo/Mladá fronta.

Greenberg, Clement (1972): Art and Culture: Critical Essays. Boston: Beton Press.

Hájek, Lubor (1956): Umění čtyř světadílů: Z českých sbírek mimoevropského umění, díl I. Praha: Orbis.

Laude, Jean (1973): Umění černého světadílu. Praha: Odeon.

Lévi-Strauss, Claude (1955; 1966): Smutné tropy. Praha: Odeon.

Lommel, Andreas (1972): Pravěk a umění prírodních národů. Praha: Artia.

Melicherčík, Ivan (2008): Africké umenie. Zbierka Ivana Melicherčíka. Bratislava: Roland Torsten Advertising.

Millerová, Judith (2007): Primitivní umění: Podrobný obrazový průvodce. Praha: Slovart.

Naumann, Jaroslav (1926): Umění člověka primitivního. Praha Svoboda.

Petrusek, Miloslav (2006): Společnosti pozdní doby. Praha: Sociologické nakladatelství.

Pijoan, José (1974-2001): Dějiny umění I.-XI. díl. Praha: Odeon - Knižní klub.

Slavíková, Zdenka (1988): Umění subsaharské Afriky. Praha: Univerzita Karlova.

Soukup, Václav (2004): Dějiny antropologie. Praha: Karolinum.

Spengler, Osvald (2010): Zánik Západu. Praha: Academia.

Toynbee, Arnold (1995): Studium dějin. Praha: Práh.

Zelený, Mnislav (2008): Malá encyklopedie bohů a mýtů Jižní Ameriky. Praha: Libri.

\section{AUTORKA}

Štěpánová, Kateřina (25. 5. 1984, Praha), česká kulturní antropoložka; absolventka Katedry teorie kultury (kulturologie) Filozofické fakulty Univerzity Karlovy v Praze. Dlouhodobě se věnuje tématu vztahu exotického umění a české kultury, přispívá $\mathrm{k}$ deskripci této opomíjené oblasti a její prezentaci. Magisterská diplomová práce: Exotické umění v České republice (obhájeno 2010); rigorózní práce: Teorie a praxe prezentace exotického umění v České republice (obhájeno 2010); disertační práce: Česká kultura a exotika (předpokládaný rok obhajoby 2013).

Kontakt: PhDr. Kateřina Štěpánová, Katedra teorie kultury (kulturologie) Filozofické fakulty Univerzity Karlovy v Praze, Celetná 20, 11000 Praha 1, e-mail: cat.erin@seznam.cz. 